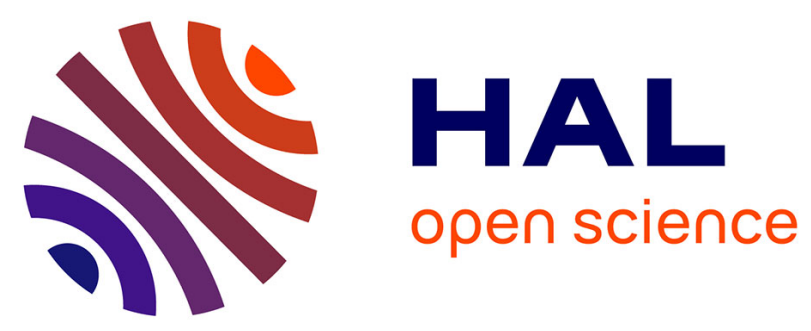

\title{
High-risk exposure without personal protective equipment and infection with SARS-CoV-2 in healthcare workers: results of the CoV-CONTACT prospective cohort
}

Sarah Tubiana, Charles Burdet, Nadhira Houhou, Michael Thy, Pauline Manchon, François Blanquart, Charlotte Charpentier, Jérémie Guedj, Loubna Alavoine, Sylvie Behillil, et al.

\section{- To cite this version:}

Sarah Tubiana, Charles Burdet, Nadhira Houhou, Michael Thy, Pauline Manchon, et al.. Highrisk exposure without personal protective equipment and infection with SARS-CoV-2 in healthcare workers: results of the CoV-CONTACT prospective cohort. 2021. pasteur-03147092

\section{HAL Id: pasteur-03147092}

https://hal-pasteur.archives-ouvertes.fr/pasteur-03147092

Preprint submitted on 5 May 2021

HAL is a multi-disciplinary open access archive for the deposit and dissemination of scientific research documents, whether they are published or not. The documents may come from teaching and research institutions in France or abroad, or from public or private research centers.

$$
\text { Copyright }
$$

L'archive ouverte pluridisciplinaire $\mathbf{H A L}$, est destinée au dépôt et à la diffusion de documents scientifiques de niveau recherche, publiés ou non, émanant des établissements d'enseignement et de recherche français ou étrangers, des laboratoires publics ou privés. 
medRxiv preprint doi: https://doi.org/10.1101/2020.09.17.20194860; this version posted September 18, 2020. The copyright holder for this

2 Title

3 High-risk exposure without personal protective equipment and infection with SARS-CoV-2 in

4 healthcare workers: results of the CoV-CONTACT prospective cohort

5

\section{Authors}

7 Sarah Tubiana ${ }^{1,2,3,{ }^{*}}$, Charles Burdet ${ }^{1,2,4,{ }^{*}}$, Nadhira Houhou ${ }^{5}$, Michael Thy ${ }^{1}$, Pauline Manchon ${ }^{1,4}$,

8 François Blanquart ${ }^{2,6}$, Charlotte Charpentier ${ }^{2,5}$, Jérémie Guedj ${ }^{1,2}$, Loubna Alavoine ${ }^{1}$, Sylvie Behillii ${ }^{7,8}$,

9 Anne Leclercq $^{9}$, Jean-Christophe Lucet ${ }^{2,10}$, Yazdan Yazdanpanah ${ }^{2,11}$, Mikaël Attia $^{12}$, Caroline Demeret ${ }^{7}$,

10 Thierry Rose ${ }^{13}$, Julia Anna Bielicki ${ }^{14,15}$, Patricia Bruijning-Verhagen ${ }^{16}$, Herman Goossens ${ }^{17}$, Diane

11 Descamps ${ }^{2,5}$, Sylvie van der Werf ${ }^{7,8}$, Bruno Lina ${ }^{18,19}$, Xavier Duval ${ }^{1,2}$

$12 *$ Contributed equally

1 AP-HP, Hôpital Bichat, Centre d'Investigation Clinique, Inserm CIC 1425, F-75018 Paris, France

2 Université de Paris, IAME, INSERM, F-75018 Paris, France

3 AP-HP, Hôpital Bichat, Centre de Ressources Biologiques, F-75018 Paris, France

4 AP-HP, Hôpital Bichat, Département d'Epidémiologie, Biostatistique et Recherche, F-75018 Paris,

France

5 AP-HP, Hôpital Bichat, Laboratoire de Virologie, F-75018 Paris, France

6 Center for Interdisciplinary Research in Biology (CIRB), Collège de France, CNRS, INSERM, PSL

Research University, Paris, France

7 Molecular Genetics of RNA Viruses, Department of Virology, CNRS UMR3569, Université de Paris, Institut Pasteur, Paris, France

8 National Reference Center for Respiratory Viruses, Institut Pasteur, Paris, France

9 AP-HP, Beaujon Hospital, Direction des soins, F-92118 Clichy, France. 
medRxiv preprint doi: https://doi.org/10.1101/2020.09.17.20194860; this version posted September 18, 2020. The copyright holder for this preprint (which was not certified by peer review) is the author/funder, who has granted medRxiv a license to display the preprint in perpetuity.

All rights reserved. No reuse allowed without permission.

27

\section{Corresponding author} Pasteur, Paris, France The Netherlands 69004, Lyon, France

\section{Keywords}

\section{Running title}

Xavier Duval
11 AP-HP, Hôpital Bichat, Service de Maladies Infectieuses et tropicales, F-75018 Paris, France

12 Physique des fonctions biologiques, CNRS UMR3738, Institut Pasteur, Paris, France

13 Biologie cellulaire des lymphocytes, INSERM - U1221, Department of Immunology, Institut

14 Paediatric Infectious Diseases Research Group, Institute for Infection and Immunity, St George's University of London, London SW17 ORE, UK

13 Paediatric Pharmacology and Paediatric Infectious Diseases, University of Basel Children's 5Hospital, Basel, Switzerland

16 Julius Center for Health Sciences and Primary Care, University Medical Center Utrecht, Utrecht,

17 Laboratory of Medical Microbiology, Vaccine and Infectious Disease Institute, Faculty of Medicine and Health Science, University of Antwerp, Antwerp, Belgium

$18 \mathrm{CIRI}$, Centre International de Recherche en Infectiologie, (Team VirPath), Univ Lyon, Inserm, U1111, Université Claude Bernard Lyon 1, CNRS, UMR5308, ENS de Lyon, F-69007, Lyon, France 19 Laboratoire de Virologie, Centre National de Référence des Virus des infections respiratoires (dont la grippe), Institut des Agents Infectieux, Groupement Hospitalier Nord, Hospices Civils de Lyon,

SARS-CoV-2; healthcare workers; high-risk exposure; personal protective equipment; transmission

SARS-CoV-2 infection in healthcare workers 
medRxiv preprint doi: https://doi.org/10.1101/2020.09.17.20194860; this version posted September 18, 2020. The copyright holder for this preprint (which was not certified by peer review) is the author/funder, who has granted medRxiv a license to display the preprint in perpetuity. All rights reserved. No reuse allowed without permission.

53 Centre d'Investigation Clinique

54 Hôpital Bichat Claude Bernard

55 46, rue Henri Huchard

5675018 Paris, France

$57 \quad$ Tel: +33140257148

$58 \quad$ Fax : +331402567 76

59 e-mail: xavier.duval@aphp.fr

60

61

\section{Word count}

$63 \quad 2510$ 
medRxiv preprint doi: https://doi.org/10.1101/2020.09.17.20194860; this version posted September 18, 2020. The copyright holder for this preprint (which was not certified by peer review) is the author/funder, who has granted medRxiv a license to display the preprint in perpetuity.

All rights reserved. No reuse allowed without permission.

\section{Abstract}

65 Objective: We aimed to estimate the risk of infection in Healthcare workers (HCWs) following a highrisk exposure without personal protective equipment (PPE).

Methods: We conducted a prospective cohort in HCWs who had a high-risk exposure to SARS-CoV-2infected subject without PPE. Daily symptoms were self-reported for 30 days, nasopharyngeal swabs for SARS-CoV-2 RT-PCR were performed at inclusion and at days 3, 5, 7 and 12, SARS-CoV-2 serology was assessed at inclusion and at day 30. Confirmed infection was defined by positive RT-PCR or seroconversion, and possible infection by one general and one specific symptom for two consecutive days.

Results: Between February $5^{\text {th }}$ and May $30^{\text {th }}, 2020,154$ HCWs were enrolled within 14 days following one high-risk exposure to either a hospital patient $(70 / 154 ; 46.1 \%)$ and/or a colleague $(95 / 154$; $62.5 \%)$. At day $30,25.0 \%$ had a confirmed infection $(37 / 148 ; 95 \% \mathrm{Cl}, 18.4 \% ; 32.9 \%)$, and $43.9 \%$ $(65 / 148 ; 95 \% \mathrm{Cl}, 35.9 \% ; 52.3 \%)$ had a confirmed or possible infection. Factors independently associated with confirmed or possible SARS-CoV-2 infection were being a pharmacist or administrative assistant rather than being from medical staff (adjusted $O R \quad(a O R)=3.8$, $\mathrm{Cl} 95 \%=1.3 ; 11.2, \mathrm{p}=0.01)$, and exposure to a SARS-CoV-2-infected patient rather than exposure to a SARS-CoV-2-infected colleague ( $a O R=2.6, C \mid 95 \%=1.2 ; 5.9, p=0.02$ ). Among the $26 \mathrm{HCWs}$ with a SARSCoV-2-positive nasopharyngeal swab, 7 (26.9\%) had no symptom at the time of the RT-PCR positivity. Conclusions: The proportion of HCWs with confirmed or possible SARS-CoV-2 infection was high. There were less occurrences of high-risk exposure with patients than with colleagues, but those were associated with an increased risk of infection. 
medRxiv preprint doi: https://doi.org/10.1101/2020.09.17.20194860; this version posted September 18, 2020. The copyright holder for this

\section{Main text}

\section{Introduction}

Since December 2019, severe acute respiratory syndrome coronavirus 2 (SARS-CoV-2) which causes

COVID-19, rapidly spread around the globe $[1,2]$. The difficulty to control its rapid propagation is

related to many factors, including the fact that infectiousness can precede the symptoms onset,

91 thereby complicating the identification and isolation of infected individuals before they can transmit

92 the virus [3, 4].

93 Healthcare workers (HCWs) can be infected following a contact with a patient, but also after

94 interactions with colleagues, or in the community [5-12]. The use of personal protective equipment

95 (PPE) was rapidly implemented in departments hosting suspected or identified SARS-CoV-2-infected

96 subjects. However, the atypical presentation of the infection favors high risk contacts between HCW

97 and unidentified patients in other departments [3], and the large circulation of the virus increases

98 the risk of infection during interactions with colleagues, during which the use of PPE or social

99 distancing may be less strictly followed [13].

We conducted a prospective cohort study to estimate the risk of infection in HCWs following high-

risk exposure in the hospital, and to evaluate the virological, immunological and clinical outcomes

102 following exposure.

103

104

Methods

\section{Study design and participants}

The CoV-CONTACT study is an ongoing prospective multicenter cohort study including HCWs with exposure to an "index" SARS-CoV-2-infected person (either a patient or a colleague) whose infection was virologically proven by a nasopharyngeal RT-PCR and whose exposure was considered at highrisk of SARS-CoV-2 transmission. HCWs were included in the study in the 14 days following the last identified high-risk exposure. The present analysis focuses on "contact" subjects enrolled at the 
medRxiv preprint doi: https://doi.org/10.1101/2020.09.17.20194860; this version posted September 18, 2020. The copyright holder for this

$111>1000$ bed Bichat Claude Bernard University Hospital (Paris, France) [14] between March, $3^{\text {rd }} 2020$

112 and April, $27^{\text {th }} 2020$.

\section{Ethics and regulatory issues}

114 The study was approved by the French National Data Protection Commission (approval \#920102),

115 and the French Ethics committee (CPP-lle-de-France-6, \#2020-A00280-39) and was registered on the

116 Clinicaltrial.gov registry (NCT04259892). All subjects provided written informed consent.

\section{Definition of high-risk exposure}

118

121

Exposure was considered to be at high-risk of SARS-CoV-2 transmission if it occurred i) face-to-face, within one meter and without protective surgical or FFP2/N95 mask, and ii) during a discussion or while the index had an episode of coughing or sneezing, and iii) in the 72 hours prior to, or following the virological diagnosis, or during the symptomatic period of the index.

\section{Data collection}

Collected characteristics of the index included age, date of the diagnostic nasopharyngeal RT-PCR and the SARS-CoV-2 viral load [15].

The collected characteristics of the contacts included medical history, weight, height, current medications, and smoking status. The date of the last high-risk exposure, D0, with the index were also recorded, as well as the cumulative exposure duration.

Contacts were followed up for 30 days following D0. Nasopharyngeal swabs were performed at inclusion, and then at D3, D5, D7 and D12. As inclusion could occur up to 14 days after D0, a maximum of five nasopharyngeal swabs could be collected. Blood samples were drawn at inclusion and D30 \pm 7 f for SARS-CoV-2 serology.

A set of general symptoms (fever $>38^{\circ} \mathrm{C}$, fatigue, myalgia, headache) and specific symptoms (cough, breathing difficulties, sore throat, nasal congestion, anosmia, diarrhea) was recorded daily from D0 to D30 using self-administered questionnaires. Results of any additional nasopharyngeal swab were 
medRxiv preprint doi: https://doi.org/10.1101/2020.09.17.20194860; this version posted September 18, 2020. The copyright holder for this

collected, as well as the occurrence of hospitalization, or the existence of household contacts

hospitalized for a SARS-CoV-2 infection between D0 and D30.

The SARS-CoV-2 RT-PCR was performed blinded to contact characteristics and reported symptoms (see Supplementary appendix).

In contacts with clinical signs suggestive of COVID-19 but a negative SARS-CoV-2 RT-PCR and a negative SARS-CoV-2 serology at D30, a multiplex RT-PCR (QIAstat-Dx Respiratory Panel; Qiagen, Germany) was retrospectively performed on available aliquots to detect other respiratory pathogens (see Supplementary appendix).

SARS-CoV-2 serology was performed blinded to contacts' characteristics and reported symptoms. We used two methods targeting different SARS-CoV-2 antigens: LuLISA N, an in-house Luciferase-Linked Immunosorbent assay designed to detect IgG targeted toward SARS-CoV-2 $\mathrm{N}$ antigen (unpublished results) and EurolMMUN, a commercial immunoassay used for the detection of IgG targeted toward the SARS-CoV-2 recombinant Spike protein subunit (S1) [16]. A serum was considered as positive for SARS-CoV-2 antibodies when the signal exceeded the threshold set at 13,402 relative light units per second (RLU/s) for LuLISA or a 1.1 ratio for EurolMMUN.

For each method, we defined SARS-CoV-2 seroconversion as the apparition of a positive SARS-CoV-2 serology at the D30 visit, or as an at least two-fold increase of the LuLISA signal or EurolMMUN ratio between inclusion and D30, in the case of a positive serology at inclusion.

\section{Definition of SARS-CoV-2 infection}

156 Three definitions of SARS-CoV-2 infection were used: (i) "clinically-suspected infection", when the

157 contact reported at least one general symptom and one specific symptom during two consecutive 158 days during the 30-day follow-up; (ii) "virologically-proven infection", if the contact had at least one 
medRxiv preprint doi: https://doi.org/10.1101/2020.09.17.20194860; this version posted September 18, 2020. The copyright holder for this

SARS-CoV-2-positive nasopharyngeal swab during the 30-day follow-up; (iii) "immunologically-proven

160 infection" if the contact exhibited a SARS-CoV-2 seroconversion in any of the two methods.

161 SARS-CoV-2 infection was considered as confirmed if it was virologically or immunologically-proven,

162 and considered as possible in case of clinically-suspected infection only.

163 The primary endpoint was confirmed or possible SARS-CoV-2 infection, thereafter referred to as

164 SARS-CoV-2 infection.

165

166

167

168

\section{Statistical methods}

Categorical variables are expressed as counts (percentage) and continuous variables are expressed as median (IQR). We first estimated the prevalence of SARS-CoV-2 infection among HCWs, with its $95 \%$ confidence intervals computed using the binomial distribution. For the primary endpoint, in case of missing data for one of the components, the subject was considered as infected if one of the available components of the endpoint fulfilled the definition of infection, and considered missing otherwise.

We searched for risk factors associated with SARS-CoV-2 infection among HCWs. Variables achieving a p-value $<0.20$ in univariate logistic regression analysis were entered into a multivariate logistic regression analysis. Using a backward selection method, we obtained a final model in which all risk factors had a p-value <0.05.. A sensitivity analysis was performed after exclusion of the subpopulation who only met the definition of a possible SARS-CoV-2 infection.

We then studied the kinetics of the SARS-CoV-2 infection in participants with virologically-proven and clinically-suspected infection. We analyzed the SARS-CoV-2 viral load as a function of time from symptom onset using a quadratic regression model..

Analyses were performed with R v3.5 (R Foundation for Statistical Computing, Vienna, Austria). All tests were two-sided with a type-l error fixed to 0.05 . 
medRxiv preprint doi: https://doi.org/10.1101/2020.09.17.20194860; this version posted September 18, 2020. The copyright holder for this preprint (which was not certified by peer review) is the author/funder, who has granted medRxiv a license to display the preprint in perpetuity.

All rights reserved. No reuse allowed without permission.

Results

\section{Contacts characteristics and type of exposure}

Overall, $154 \mathrm{HCW}$ s exposed to 44 COVID-19 index subjects were included. The median age of these contacts was 35 years (IQR 29.0; 46.8), 35/154 were male (22.7\%). High-risk exposure occurred prior to the widespread use of masks in the hospital (on March, $18^{\text {th }}$ ) in $88 / 154$ contacts (57\%). In contrast, the exposure to colleagues increased from $31.8 \%(28 / 88)$ before March, $18^{\text {th }}$ to $88.2 \%(60 / 68)$ after March, $18^{\text {th }}$ ( 2 contacts with combined exposures). Overall $28 / 154$ contacts $(18.2 \%)$ had a high-risk exposure with more than one index subject. enrolled at a median time of 6.5 days (IQR $4 ; 8)$ after D0. Table 1 presents the characteristics of the included contacts; $51 / 154$ (33.1\%) were medical doctors, midwifes, or residents; $77 / 154$ (50.0\%) were nurses, nursing assistant, physiotherapists or hospital students. Contacts were exposed to patients $(70 / 152,46.1 \%)$ or colleagues $(95 / 152,62.5 \%)$ of whom $13 / 152$ (8.6\%) were exposed to both patients and colleagues.

While the exposure to patients represented $68.2 \%(60 / 88)$ of high-risk exposure before March $18^{\text {th }}$, this number dropped to only $11.8 \%(8 / 68)$ after March $18^{\text {th }}$. Most contacts had a cumulated exposure of more than 30 minutes $(102 / 151,67.5 \%)$. In the 95 contacts exposed to an index colleague, exposure was related to face-to-face discussion (89/95, 93.7\%), meetings (26/95, 27.4\%), lunch sharing $(20 / 95,21.1 \%)$, and other $(10 / 95,10.5 \%)$.

204 Overall, $26 / 154$ contact subjects $(16.9 \%, 95 \% \mathrm{Cl}[11.3 \% ; 23.8 \%])$ had at least one SARS-CoV-2-positive nasopharyngeal swab (see details in supplementary appendix). When positive, the median nasopharyngeal SARS-CoV-2 viral load was $8.7 \log _{10}$ copies/ml (IQR 6.5; 9.4). 
medRxiv preprint doi: https://doi.org/10.1101/2020.09.17.20194860; this version posted September 18, 2020. The copyright holder for this preprint (which was not certified by peer review) is the author/funder, who has granted medRxiv a license to display the preprint in perpetuity.

All rights reserved. No reuse allowed without permission.

207

208

209

210

211

212

213

Overall, 147 of the 154 contacts had both inclusion and D30 sera samples. At inclusion, 15/147 (10\%) contacts had a positive serology by one of the two methods. At D30, 31/147 (21.1\%, $95 \% \mathrm{Cl}[14.8 \%$; 28.6\%]) contacts exhibited a seroconversion. Results obtained by the two serological methods are presented in Table S1.

Based on self-administered questionnaires, $61 / 151(40.4 \%, 95 \% \mathrm{Cl}[32.5 \% ; 48.7 \%])$ contacts met the definition of a clinical infection (see details in supplementary appendix). The median duration of symptoms was 5.5 days (IQR $3 ; 9.2$ ).

The Figure 1 presents the combination of virological, immunological and clinical outcomes; 28 contacts fulfilled only the clinical definition of infection. In these subjects, the prevalence of symptoms dropped at day 10 , whereas it persisted elevated until day 30 in those with confirmed infection (Figure 2).

\section{Proportion of contacts with SARS-CoV-2 infection}

At D30, among the 148 contacts with available data, 65 met the criteria of confirmed or possible SARS-CoV-2 infection (43.9\%, 95\%Cl [35.9\%; 52.3\%]), confirmed in $37(25.0 \%, 95 \% \mathrm{Cl}$ [18.4\%; 32.9\%]), and possible (i.e., only clinically-suspected) in $28(18.9 \%, 95 \% \mathrm{Cl}$ [13.2\%; 26.5\%]). Figure S1 presents the different clusters of exposure from the 44 index subjects. Among the 28 contacts with possible SARS-CoV-2 infection, multiplex RT-PCR for other respiratory viruses could be performed in 21 and was negative for 19 patients and positive for two (one bocavirus and one rhinovirus). During followup, one contact with confirmed SARS-CoV-2 infection was hospitalized. There was no hospitalization for SARS-CoV-2 infection reported in their household contacts.

\section{Factors associated with SARS-CoV-2 infection}

In the multivariable analysis, the variables associated with SARS-CoV-2 infection were being a pharmacist or administrative assistant $(\mathrm{OR}=3.8, \mathrm{C} \mid 95 \%=1.3 ; 11.2, \mathrm{p}=0.01)$ and having a contact with a SARS-CoV-2-infected patient (OR=2.6, $\mathrm{Cl} 95 \%=1.23 ; 5.9, \mathrm{p}=0.02)$. 
medRxiv preprint doi: https://doi.org/10.1101/2020.09.17.20194860; this version posted September 18, 2020. The copyright holder for this

preprint (which was not certified by peer review) is the author/funder, who has granted medRxiv a license to display the preprint in perpetuity.

All rights reserved. No reuse allowed without permission.

231 The results of the sensitivity analysis excluding contacts having only a possible SARS-CoV-2 infection

232 provided similar results except for pharmacist or administrative assistants' function (Table S2).

\section{Viral dynamics in infected contacts}

234 The viral load as a function of time since symptom onset reached a maximum at $8.8 \log _{10} \operatorname{copies} / \mathrm{ml} 4$

235 days after symptom onset followed by a decline afterwards (Figure 3 ). Of note, 7/25 subjects had a

236 positive SARS-CoV-2 nasopharyngeal swab before the symptoms onset and the first positive

237 nasopharyngeal swab was observed as early as six days before symptoms onset. In eight subjects, the

238 positive swab was preceded by one negative swab and in two of them, the negative swab was done

239 after the symptom onset.

\section{Discussion}

In this prospective cohort of high-risk exposed HCWs, between $25 \%$ and $44 \%$ of subjects acquired

SARS-CoV-2 infection at day 30, depending on the definition used to assess infection. Viral shedding

occurred before symptoms onset in $27 \%$ of the SARS-CoV-2-positive subjects. The majority of HCWs

were exposed to a SARS-CoV-2-infected colleague (62.5\%), and a substantial proportion had a high-

risk contact with a patient (46.1\%). Exposure with a SARS-CoV-2-infected patient was significantly

associated with SARS-CoV-2 infection ( $p=0.023)$.

The HCWs included in our analysis reflected the diversity of the hospital workers, [17] offering an 
medRxiv preprint doi: https://doi.org/10.1101/2020.09.17.20194860; this version posted September 18, 2020. The copyright holder for this preprint (which was not certified by peer review) is the author/funder, who has granted medRxiv a license to display the preprint in perpetuity. All rights reserved. No reuse allowed without permission.

256 likely that activities involving a close contact with patients favor infection, such association might

257 have been masked as HCWs could also be infected by colleagues.

258 One of the strengths of our study is its prospective design, with daily self-questionnaire to 259 characterize symptoms onset and evolution, as well as repeated nasopharyngeal swabs to capture 260 the time of infection after exposure, and serological assessments at inclusion and at day 30 . The $10 \%$ 261 seropositivity of HCWs at inclusion corresponds to the seroprevalence reported in the Paris area in 262 the general population during this period, [18] and it is plausible that these subjects had been 263 infected prior to the high-risk exposure identified in the study. Seroconversion was observed in about 264 a third of exposed HCWs classified as infected, while their nasopharyngeal swabs were negative; 265 most of these HCWs were symptomatic. Inversely a quarter of the HCWs with a SARS-CoV-2-positive 266 nasopharyngeal swabs had no detectable antibodies at day 30, despite the use of two serological 267 techniques. The prospective nature of our analysis allowed us to characterize the time to viral positivity in the 26 subjects with SARS-CoV-2-positive nasopharyngeal swabs and the relationship between the viral load and the time since symptom onset. Nasopharyngeal viral load could be positive before symptom onset, with the first positive viral load obtained as early as six days before symptom onset, consistent with the estimated 6-day incubation period previously reported [19, 20]. In addition to these confirmed infections, we also considered possible infections, as defined by the presence of one general and one specific symptoms for two consecutive days in subjects with neither a positive PCR nor seroconversion. Our definition is stricter than what was done in other studies [17, 21-23]. Interestingly we found that the kinetics of symptom onset was very similar in confirmed and possibly infected subjects, with $20-35 \%$ of subjects presenting symptom between day 4 and day 15

277 after their last high-risk exposure. The possibly infected patients had a lower prevalence of symptoms as time went by, with a rapid reduction of prevalence around day 15 , while subjects with confirmed infection had a prevalence of symptoms that remained larger than $20 \%$ until day 30 . The faster clearance of symptoms in possible infections suggests that these patients had a milder disease, 
medRxiv preprint doi: https://doi.org/10.1101/2020.09.17.20194860; this version posted September 18, 2020. The copyright holder for this preprint (which was not certified by peer review) is the author/funder, who has granted medRxiv a license to display the preprint in perpetuity. All rights reserved. No reuse allowed without permission.

282 they did not exhibit detectable antibodies. Future analyses, that will include the probabilistic analysis

283 of their serial negative nasopharyngeal swab results, as well as the study of the immune cellular

284 response, will provide more conclusive evidence on their infection status [24].

285 A major limitation of our study is the absence of whole genome sequencing comparing the virus of

286 the index subject and SARS-CoV-2-infected HCW. Therefore, the network of exposures and infection

287 only suggests that the infection in a subject is the consequence of a high-risk exposure. However,

288 sequencing would be restricted to RT-PCR positive subjects, which only represent $40 \%(26 / 65)$ of our

289 population of confirmed and possible infections. Another limitation was that the type of contacts

290 observed in the study has been modified by universal masking implemented on March, $18^{\text {th }}, 2020$.

291 After this date, most at risk contacts were between two HCWs, which were less likely, but not 292 unlikely, to result in SARS-CoV-2 transmission.

293 All together, the rate of transmission observed in HCWs after high-risk exposure, which could be as 294 large as 44\%, and close to a recent report [25], strengthens the conclusion that universal masking of 295 HCW, both during contacts with patients and colleagues, and at all times, is essential to prevent 296 HCWs infection and maintain hospital capacities during outbreaks [26]. 
medRxiv preprint doi: https://doi.org/10.1101/2020.09.17.20194860; this version posted September 18, 2020. The copyright holder for this

preprint (which was not certified by peer review) is the author/funder, who has granted medRxiv a license to display the preprint in perpetuity.

All rights reserved. No reuse allowed without permission.

\section{Contributors}

$298 \mathrm{ST}, \mathrm{CB}, \mathrm{XD}, \mathrm{YY}, \mathrm{JCL}, \mathrm{JB}, \mathrm{PB}$ and $\mathrm{BL}$ designed the experiments. ST, MT, LA, AL and XD included subjects.

$299 \mathrm{NH}, \mathrm{CC}, \mathrm{DD}$, SvW and BL performed the biological analyses. ST, CB, PM, FB, JG and XD analyzed the data. ST, CB, PM, FB, JG CC, DD, SvW, BL and XD interpreted the results. ST, CB, FB, and XD wrote the Article. All authors reviewed and approved the manuscript before submission.

Funding

The study was founded by Reacting, the French Ministry of Health (PHRC-N COVID-19, project PHRC20-0242) and the European Commission (RECoVer, grant agreement 101003589). Some authors received financial support of the national research agency (ANR) through the ANR-Flash calls for

Declaration of interests

The authors have no commercial or other associations that might pose a conflict of interest.

\section{Acknowledgments}

CoVCONTACT study group

Principal investigator: Duval Xavier

Steering Committee: Burdet Charles, Duval Xavier, Lina Bruno, Tubiana Sarah, Van Der Werf Sylvie

CoV-CONTACT Clinical Centers: Abad Fanny, Abry Dominique, Alavoine Loubna, Allain Jean-

Bertholon Fréderique,Boissel Nolwenn, Botelho-Nevers Elisabeth, Bouiller Kévin, Bourgeon Marilou,

Boutrou Mathilde, Brick Lysiane, Bruneau Léa, Caumes Eric, Chabouis Agnès, Chan Thien Eric,

320 Chirouze Catherine, Coignard Bruno, Costa Yolande, Costenoble Virginie, Cour Sylvie, Cracowski

Claire, Cracowski Jean Luc, Deplanque Dominique, Dequand Stéphane, Desille-Dugast Mireille, 
medRxiv preprint doi: https://doi.org/10.1101/2020.09.17.20194860; this version posted September 18, 2020. The copyright holder for this preprint (which was not certified by peer review) is the author/funder, who has granted medRxiv a license to display the preprint in perpetuity. All rights reserved. No reuse allowed without permission.

Faurous William, Fortuna Viviane, Fouchard Julie, Gantier Emilie, Gautier Céline, Gerardin Patrick, Gerset Sandrine, Gilbert Marie, Gissot Valérie, Guillemin Francis, Hartard Cédric, Hazevis Béatrice, Hocquet Didier, Hodaj Enkelejda, Ilic-Habensus Emila, Jeudy A, Jeulin Helene, Kane Maty,Kasprzyk Emmanuelle, Kikoine John, Laine Fabrice, Laviolle Bruno, Lebeaux David, Leclercq Anne, Ledru Eric, Lefevre Benjamin, Legoas Carole, Legrand Amélie, Legrand Karine, Lehacaut Jonathan, Lehur Claire, Lemouche Dalila, Lepiller Quentin, Lepuil Sévérine, Letienne Estelle, Lucarelli Aude, Lucet JeanChristophe, Madeline Isabelle, Maillot Adrien, Malapate Catherine, Malvy Denis, Mandic Milica, Marty-Quinternet Solène, Meghadecha Mohamed, Mergeay-Fabre Mayka, Mespoulhe Pauline, Meunier Alexandre, Migaud Maria-Claire, Motiejunaite Justina, Nathalie Gay, Nguyen Duc, Oubbea Soumaya, Pagadoy Maïder, Paris Adeline, Paris Christophe, Payet Christine, Peiffer-Smadja Nathan, Perez Lucas, Perreau Pauline, Pierrez Nathalie, Pistone Thierry, Postolache Andreea, Rasoamanana Patrick, Reminiac Cécile, Rexah Jade, Roche-Gouanvic Elise, Rousseau Alexandra, Schoemaecker Betty, Simon Sandrine, Soler Catherine, Somers Stéphanie, Sow Khaly, Tardy Bernard, Terzian Zaven, Thy Michael, Tournier Anne, Tyrode Sandrine, Vauchy Charline, Verdon Renaud, Vernet Pauline, Vignali Valérie, Waucquier Nawal

Coordination and statistical analyses: Burdet Charles, Do Thi Thu Huong, Laouénan Cédric, Mentre France, Pauline Manchon, Tubiana Sarah, Dechanet Aline, Letrou Sophie, Quintin Caroline, Frezouls Wahiba

Virological lab: Le Hingrat Quentin, Houhou Nadhira, Damond Florence, Descamps Dianes, Charpentier Charlotte, Visseaux Benoit, Vabret Astrid, Lina Bruno, Bouscambert Maud, Van Der Werf Sylvie, Behillil Sylvie, Gaillanne Laurence, Benmalek Nabil, Attia Mikael, Barbet Marion, Demeret Caroline, Rose Thierry, Petres Stéphane, Escriou Nicolas, Barbet Marion, Petres Stéphane, Escriou Nicolas, Goyard Sophie

Biological center: Kafif Ouifiya, Piquard Valentine, Tubiana Sarah

Partners: RECOVER, REACTING, Santé Publique France (Coignard Bruno, Mailles Alexandra), Agences régionales de santé (Simondon Anne, Dreyere Marion, Morel Bruno, Vesval Thiphaine)

Sponsor: Inserm 
medRxiv preprint doi: https://doi.org/10.1101/2020.09.17.20194860; this version posted September 18, 2020. The copyright holder for this preprint (which was not certified by peer review) is the author/funder, who has granted medRxiv a license to display the preprint in perpetuity. All rights reserved. No reuse allowed without permission.

350 Amat Karine, Ammour Douae, Aqourras Khadija, Couffin-Cadiergues Sandrine, Delmas Christelle,

351 Desan Vristi, Doute Jean Michel, Esperou Hélène, Hendou Samia, Kouakam Christelle, Le Meut

352 Guillaume, Lemestre Soizic, Leturque Nicolas, Marcoul Emmanuelle, Nguefang Solange, Roufai Layidé

353 Genetic: Laurent Abel, Sophie Caillat-Zucman

354 ClinicalTrial. Gov identification number: NCT04259892

355 
medRxiv preprint doi: https://doi.org/10.1101/2020.09.17.20194860; this version posted September 18, 2020. The copyright holder for this preprint (which was not certified by peer review) is the author/funder, who has granted medRxiv a license to display the preprint in perpetuity.

All rights reserved. No reuse allowed without permission.

356

357

358

359

360

361

362

363

364

365

366

367

368

369

370

371

372

373

374

375

376

377

378

379

380

381

\section{References}

1. Dong E, Du H and Gardner L. An interactive web-based dashboard to track COVID-19 in real time. Lancet Infect Dis 2020;20:533-534

2. Guan WJ, Ni ZY, Hu Y, et al. Clinical Characteristics of Coronavirus Disease 2019 in China. N Engl J Med 2020;382:1708-1720

3. Arons MM, Hatfield KM, Reddy SC, et al. Presymptomatic SARS-CoV-2 Infections and Transmission in a Skilled Nursing Facility. N Engl J Med 2020;382:2081-2090

4. Cheng HY, Jian SW, Liu DP, Ng TC, Huang WT and Lin HH. Contact Tracing Assessment of COVID-19 Transmission Dynamics in Taiwan and Risk at Different Exposure Periods Before and After Symptom Onset. JAMA Intern Med 2020

5. Barrett ES, Horton DB, Roy J, et al. Prevalence of SARS-CoV-2 infection in previously undiagnosed health care workers at the onset of the U.S. COVID-19 epidemic. medRxiv 2020

6. Chou R, Dana T, Buckley DI, Selph S, Fu R and Totten AM. Epidemiology of and Risk Factors for Coronavirus Infection in Health Care Workers. Ann Intern Med 2020

7. Contejean A, Leporrier J, Canoui E, et al. Comparing dynamics and determinants of SARS-CoV-2 transmissions among health care workers of adult and pediatric settings in central Paris. Clin Infect Dis 2020

8. Lai X, Wang M, Qin C, et al. Coronavirus Disease 2019 (COVID-2019) Infection Among Health Care Workers and Implications for Prevention Measures in a Tertiary Hospital in Wuhan, China. JAMA Netw Open 2020;3:e209666

9. Qian X, Ren R, Wang $Y$, et al. Fighting against the common enemy of COVID-19: a practice of building a community with a shared future for mankind. Infect Dis Poverty 2020;9:34

10. Sikkema RS, Pas SD, Nieuwenhuijse DF, et al. COVID-19 in health-care workers in three hospitals in the south of the Netherlands: a cross-sectional study. Lancet Infect Dis 2020

11. Team. CC-R. Characteristics of Health Care Personnel with COVID-19 - United States, February 12April 9, 2020. MMWR Morb Mortal Wkly Rep 2020;69:477-481 
medRxiv preprint doi: https://doi.org/10.1101/2020.09.17.20194860; this version posted September 18, 2020. The copyright holder for this preprint (which was not certified by peer review) is the author/funder, who has granted medRxiv a license to display the preprint in perpetuity. All rights reserved. No reuse allowed without permission.

12. Zheng L, Wang $X$, Zhou $C$, et al. Analysis of the infection status of the health care workers in Wuhan during the COVID-19 outbreak: A cross-sectional study. Clin Infect Dis 2020

13. Bielicki JA, Duval X, Gobat N, et al. Monitoring approaches for health-care workers during the COVID-19 pandemic. Lancet Infect Dis 2020

14. Lescure FX, Bouadma L, Nguyen D, et al. Clinical and virological data of the first cases of COVID-19 in Europe: a case series. Lancet Infect Dis 2020;20:697-706

15. Institut Pasteur PPR-tR-PaftdoS-C-hwwidd-scr-t-r-p-a.

16. Theel ES, Harring J, Hilgart $H$ and Granger D. Performance Characteristics of Four HighThroughput Immunoassays for Detection of IgG Antibodies against SARS-CoV-2. J Clin Microbiol 2020

17. Sakurai A, Sasaki T, Kato S, et al. Natural History of Asymptomatic SARS-CoV-2 Infection. N Engl J Med 2020

18. Santé Publique France. Point épidémiologie hebdomadaire. https://www.santepubliquefrance.fr/maladies-et-traumatismes/maladies-et-infectionsrespiratoires/infection-a-coronavirus/documents/bulletin-national/covid-19-pointepidemiologique-du-23-juillet-2020. Accessed July 28, 2020.

19. Lauer SA, Grantz KH, Bi Q, et al. The Incubation Period of Coronavirus Disease 2019 (COVID-19) From Publicly Reported Confirmed Cases: Estimation and Application. Ann Intern Med 2020;172:577-582

20. Nie X, Fan L, Mu G, et al. Epidemiological Characteristics and Incubation Period of 7015 Confirmed Cases With Coronavirus Disease 2019 Outside Hubei Province in China. J Infect Dis $2020 ; 222: 26-33$

21. Council of State and Territorial Epidemiologists. Interim-20-ID-01: standardized surveillance case definition and national notification for 2019 novel coronavirus disease (COVID-19). 2020 (https://www .cste .org/ resource/ resmgr/ 2020ps/Interim -20-ID -01_COVID -19.pdf).

22. Boulware DR, Pullen MF, Bangdiwala AS, et al. A Randomized Trial of Hydroxychloroquine as Postexposure Prophylaxis for Covid-19. N Engl J Med 2020 
medRxiv preprint doi: https://doi.org/10.1101/2020.09.17.20194860; this version posted September 18, 2020. The copyright holder for this preprint (which was not certified by peer review) is the author/funder, who has granted medRxiv a license to display the preprint in perpetuity. All rights reserved. No reuse allowed without permission.

409 23. Kluytmans-van den Bergh MFQ, Buiting AGM, Pas SD, et al. Prevalence and Clinical Presentation 410 of Health Care Workers With Symptoms of Coronavirus Disease 2019 in 2 Dutch Hospitals During

411 an Early Phase of the Pandemic. JAMA Netw Open 2020;3:e209673

412 24. Gallais F, Velay A, Wendling MJ, et al. Intrafamilial Exposure to SARS-CoV-2 Induces Cellular 413 Immune Response without Seroconversion.

414 https://www.medrxiv.org/content/10.1101/2020.06.21.20132449v1 2020

415 25. Houlihan CF, Vora N, Byrne T, et al. Pandemic peak SARS-CoV-2 infection and seroconversion 416 rates in London frontline health-care workers. Lancet 2020;396:e6-e7

417 26. Houghton C, Meskell P, Delaney $H$, et al. Barriers and facilitators to healthcare workers' 418 adherence with infection prevention and control (IPC) guidelines for respiratory infectious 419 diseases: a rapid qualitative evidence synthesis. Cochrane Database Syst Rev 2020;4:CD013582 


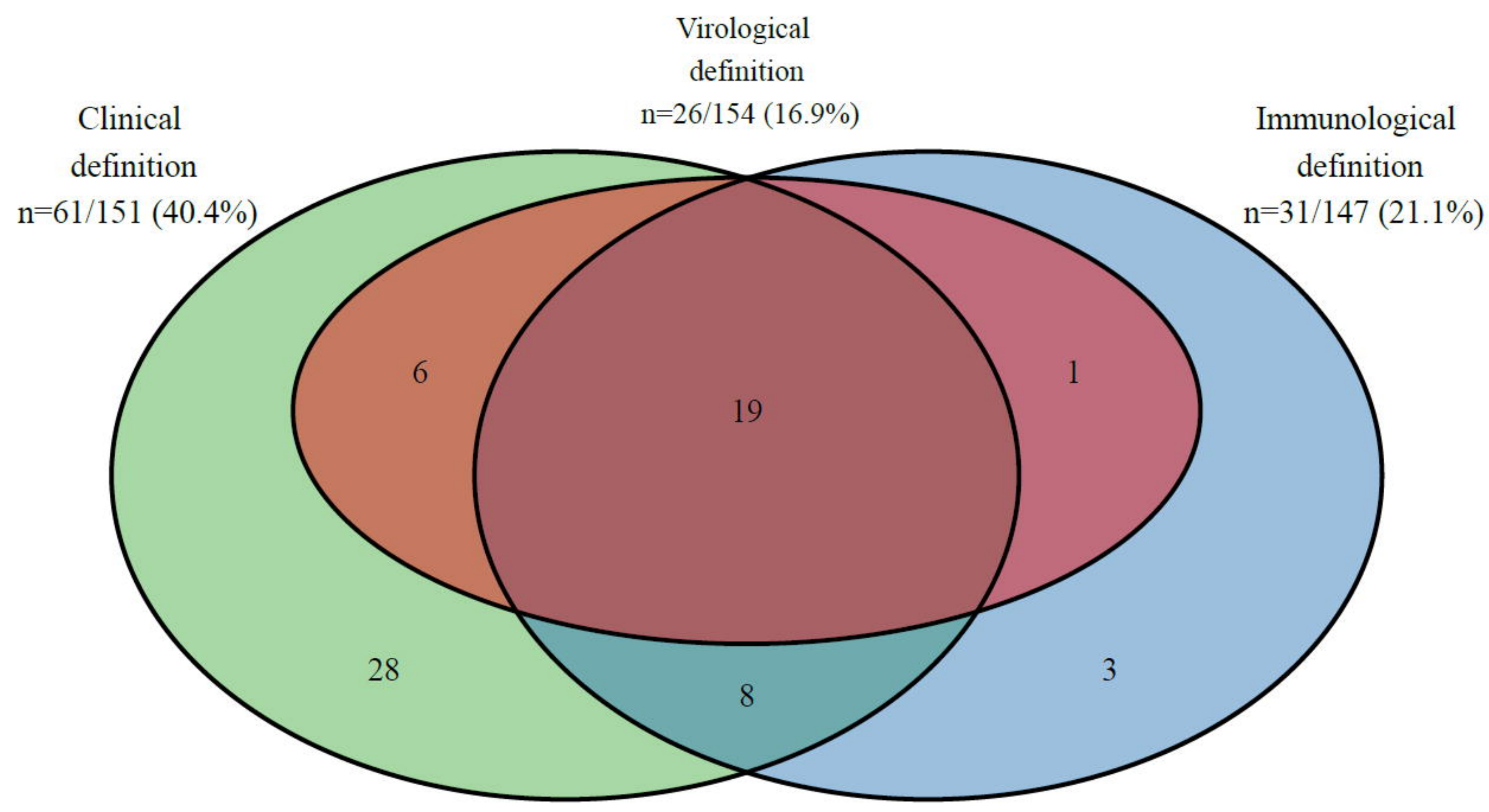




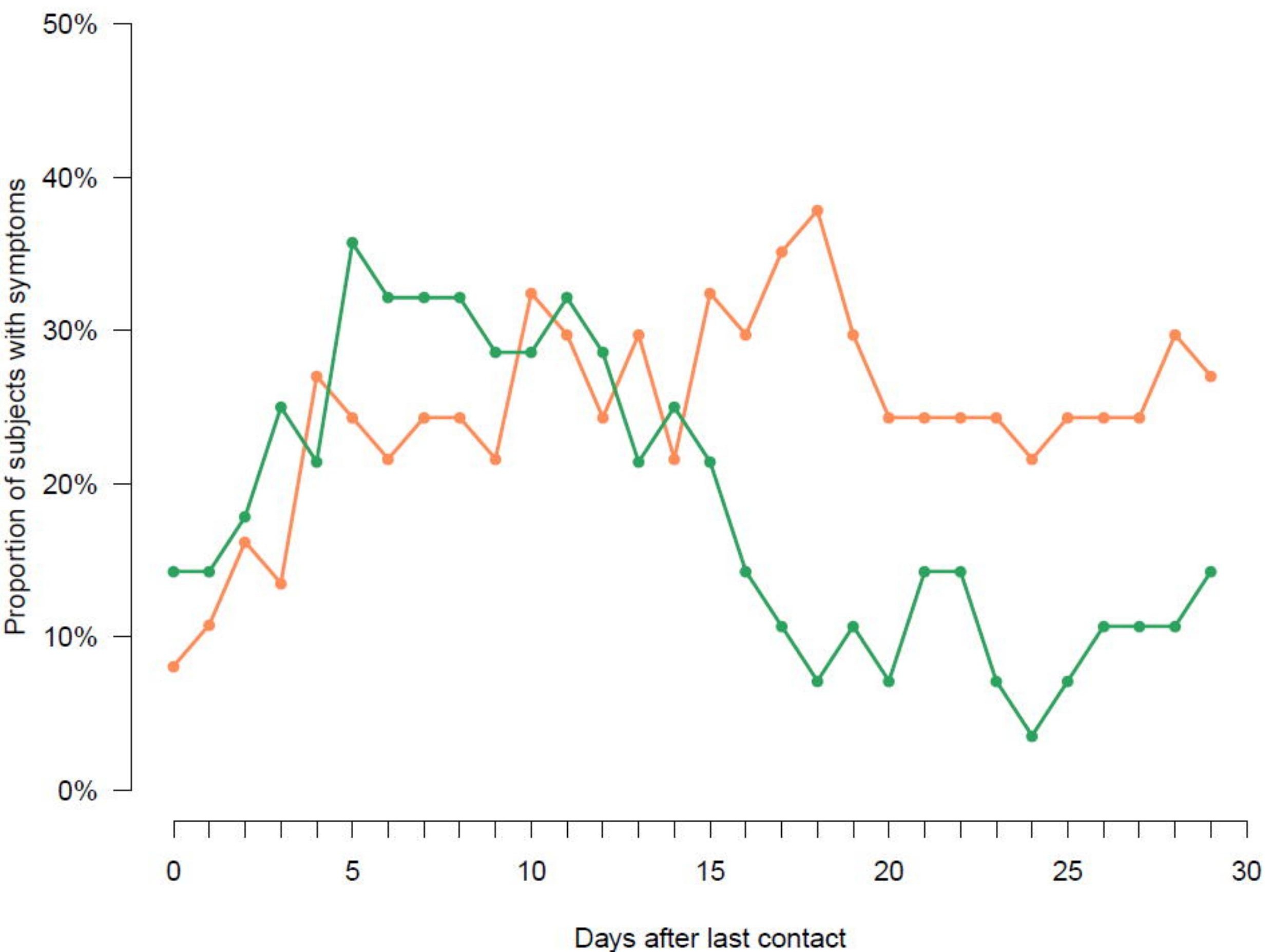




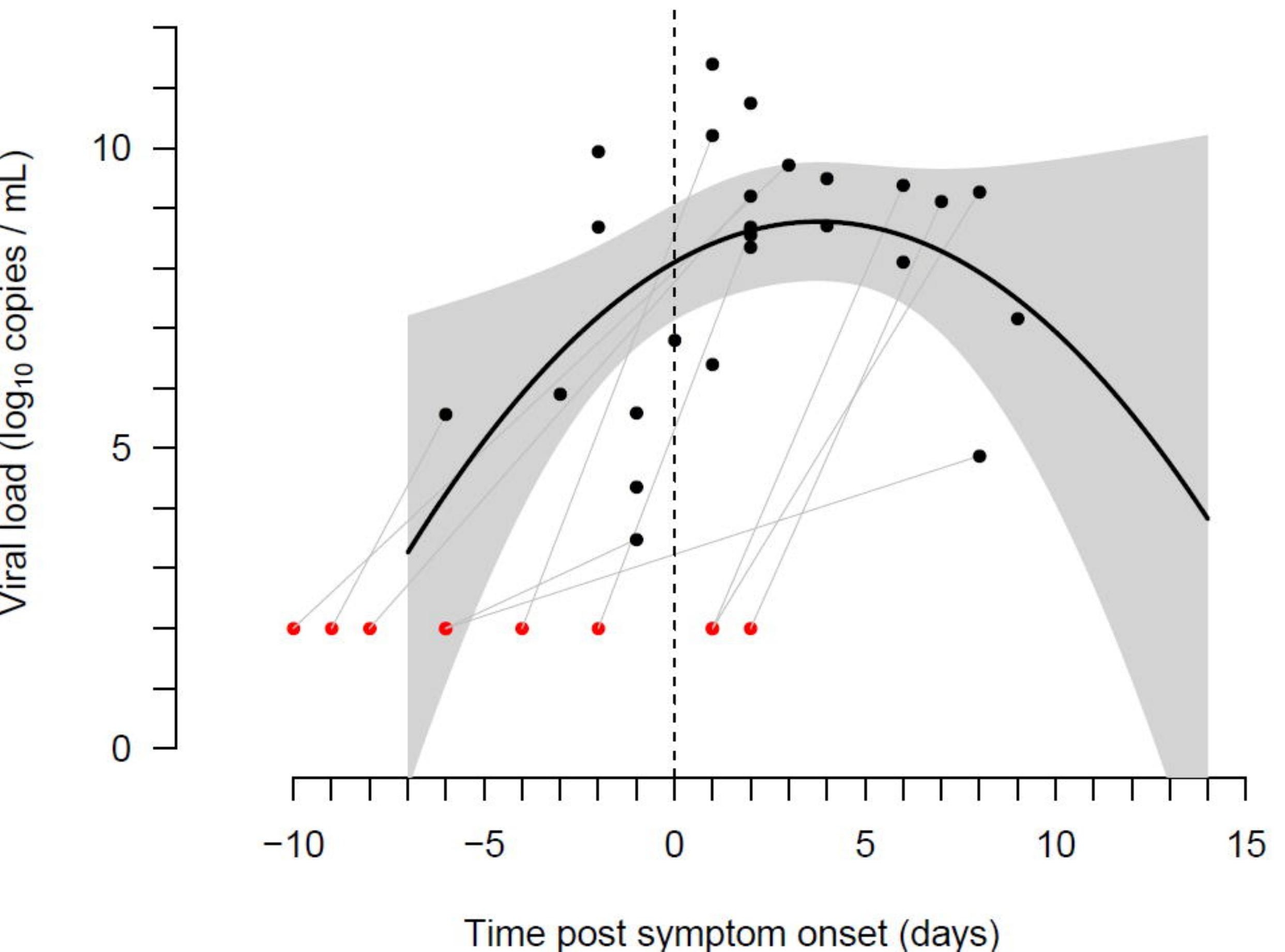




\section{Figure Legends}

\section{Figure 1}

Venn diagram of the clinical, virological and immunological outcomes among the 154 contacts included in the CoV-CONTACT cohort.

SARS-CoV-2 infection could be determined for $148 / 154$ contacts (missing data for immunological and clinical outcomes $(n=2)$, missing data for clinical outcome $(n=1)$, missing data for immunological outcome $(n=3)$.

\section{Figure 2}

Proportions of symptomatic contact subjects among the 154 contacts included in the CoV-CONTACT cohort.

The orange curve corresponds to contacts subjects with confirmed SARS-CoV-2 infection (i.e., virologically- or immunologically-proven, $n=37)$. The green curve corresponds to contacts subjects with possible SARS-CoV-2 infection (i.e., clinically-suspected without viro-immunological confirmation, $\mathrm{n}=28$ ).

\section{Figure 3}

SARS-CoV-2 viral load in the first positive SARS-CoV-2 nasopharyngeal swab as a function of time since symptom onset, in the 25 healthcare workers with a positive RT-PCR and who met the definition of clinical infection.

The first day when a specific symptom and a general symptom had been reported for two consecutive days was considered as the time of symptom onset.

The black dots show the viral loads at the first positive RT-PCR for each subject. The red dots show the time of the previous negative RT-PCR when present ( 8 subjects). The black curve is the best fitting second-order polynomial for viral load as a function of time since symptom onset, and the shaded area is the $95 \%$ confidence interval. 
medRxiv preprint doi: https://doi.org/10.1101/2020.09.17.20194860; this version posted September 18, 2020. The copyright holder for this preprint (which was not certified by peer review) is the author/funder, who has granted medRxiv a license to display the preprint in perpetuity. All rights reserved. No reuse allowed without permission.

Supplementary material for: High-risk exposure without personal protective equipment and infection with SARS-CoV-2 in healthcare workers: results of the CoV-CONTACT prospective cohort, by Tubiana et al.

\section{Supplementary Methods}

\section{Data collection}

In the case of exposure between colleagues working together, the beginning of the exposure period was fixed to 72 hours before the diagnosis of the SARS-CoV-2 infection of the index or the onset of the symptoms in the index, whichever occurred first.

\section{SARS-COV-2 RT-PCR}

Nasopharyngeal swabs were drawn by trained practitioners using Sigma Virocult ${ }^{\circledast}$ swabs (Medical Wire Instrument, UK) and processed within four hours after sampling. Nasopharyngeal swabs were manually discharged in conservation fluid according to the manufacturer recommendations. Viral RNA was extracted from $200 \mu \mathrm{L}$ of discharge fluid with the MagNA Pure LC Total Nucleic Acid Isolation Kit - Large Volume (Roche Diagnostics) and eluted in $50 \mu \mathrm{L}$. Then, SARS-CoV-2 RT-PCR was performed using the RealStar ${ }^{\circledR}$ SARS-CoV-2 RTPCR kit 1.0 (Altona Diagnostics) according to the manufacturer's instructions. This assay allows the detection and differentiation of lineage $B$-betacoronavirus ( $B-\beta C O V)$, by targeting the $E$ gene from $B-\beta C O V$, and SARS-CoV2 specific RNA, by targeting the S gene. PCR assays were performed on an ABI 7500 plateform (Applied Biosystems $\left.{ }^{\circledR}\right)$.

A signal with a cycle threshold value above 40 was considered as negative.

\section{Other respiratory pathogens RT-PCR}

Detection of other respiratory pathogens was performed using the QIAstat-Dx Respiratory Panel (Qiagen), designed for the detection of adenovirus, bocavirus, coronavirus 229E (CoV 229E), CoV HKU1, CoVNL63, CoV OC43, human metapneumovirus A and B, influenza A (FLU A), FLU A H1, FLU A H3, FLU A H1N1/2009, influenza

B, parainfluenza virus 1 (PIV 1), PIV2, PIV 3, PIV 4, human rhinovirus/enterovirus, respiratory syncytial virus A and B, Bordetella pertussis, Chlamydophila pneumoniae, and Mycoplasma pneumoniae. Approximately $300 \mu \mathrm{L}$ of discharge fluid was tested according to the manufacturer's instructions.

\section{LULISA}

The LULISA N assay makes use of a nanobody fused to luciferase for the detection of IgG antibodies binding to the SARS-CoV-2 nucleoprotein (N). Sera were used at a 1:200 dilution. The luciferase signal was measured and expressed in Relative Light Units per second (RLU/s). The threshold of positivity $(13,402 \mathrm{RLU} / \mathrm{s})$ was based on the analysis of 231 pre-pandemic sera and defined as the mean + two standard deviations 
medRxiv preprint doi: https://doi.org/10.1101/2020.09.17.20194860; this version posted September 18, 2020. The copyright holder for this preprint (which was not certified by peer review) is the author/funder, who has granted medRxiv a license to display the preprint in perpetuity. All rights reserved. No reuse allowed without permission.

Supplementary material for: High-risk exposure without personal protective equipment and infection with SARS-CoV-2 in healthcare workers: results of the CoV-CONTACT prospective cohort, by Tubiana et al.

\section{Supplementary Results}

\section{Virological, immunological and clinical outcomes}

The median number of nasopharyngeal swabs performed per contact was two (IQR 1;3), and the median time between the last high-risk exposure and the first SARS-CoV-2-positive nasopharyngeal swab was 6.5 days (IQR $4 ; 8)$.

Based on self-administered questionnaires, the most frequent symptoms being tiredness $(74 / 151 ; 49.0 \%)$, headache $(72 / 151 ; 47.7 \%)$ and myalgia $(48 / 146 ; 32.9 \%)$ among general symptoms, and nasal congestion $(52 / 148 ; 35.1 \%)$ and cough $(51 / 149 ; 34.2 \%)$ among specific symptoms. The median duration of symptoms was 5.5 days (IQR 3; 9.2).

The median number of symptoms was 5 (IQR $4 ; 6)$ among the 28 contacts with possible SARS-CoV-2 infection and was 6 (IQR $4 ; 10)$ among those with confirmed SARS-CoV-2 infection.

\section{Factors associated with SARS-CoV-2 infection}

Exposure to a SARS-CoV-2-infected patient was at higher risk of SARS-CoV-2 infection than exposure to a SARSCoV-2 colleague ( $p=0.023$, Table 1). Nurses, nurse assistants, physiotherapists and hospital students had a higher risk than medical staff $(p=0.04)$, as did pharmacists and administrative assistants $(p=0.033)$. In the multivariable analysis, the c-statistic of this final model was $0.67(95 \% \mathrm{Cl}=0.58 ; 0.76)$ and the $\mathrm{p}$-value of the Hosmer-Lemeshow test was 0.99 , showing no model misspecification. 
medRxiv preprint doi: https://doi.org/10.1101/2020.09.17.20194860; this version posted September 18, 2020. The copyright holder for this preprint (which was not certified by peer review) is the author/funder, who has granted medRxiv a license to display the preprint in perpetuity. All rights reserved. No reuse allowed without permission.

Supplementary material for: High-risk exposure without personal protective equipment and infection with SARS-CoV-2 in healthcare workers: results of the CoV-CONTACT prospective cohort, by Tubiana et al.

\section{Supplementary Figure S1}

Structure of the contact network between the 44 index subjects and the 154 healthcare workers contact subjects with high-risk exposure to SARS-CoV-2 included in the CoV-CONTACT cohort.

Blue circles are health-care workers (either index or contact subjects), green circles are SARS-CoV-2 infected index patients. Circles with crosses represent the COVID-19 index subjects.

The arrows are the exposures; the red ones are the confirmed infections (i.e., virologically- or immunologicallyproven, $n=37$ ), the orange ones are the possible infections (i.e., clinically-suspected without viroimmunological confirmation, $n=28$ ).

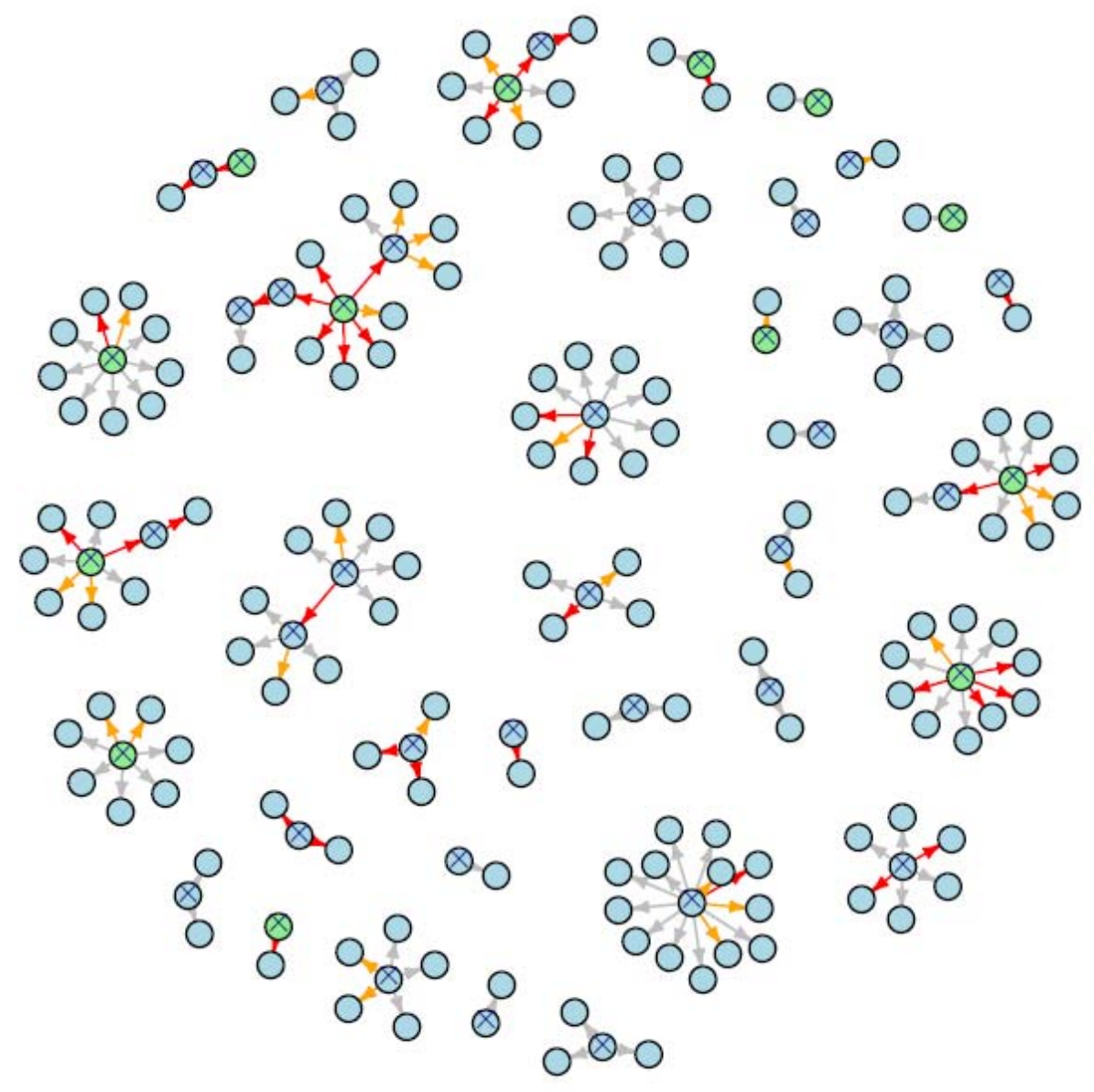


medRxiv preprint doi: https://doi.org/10.1101/2020.09.17.20194860; this version posted September 18, 2020. The copyright holder for this preprint (which was not certified by peer review) is the author/funder, who has granted medRxiv a license to display the preprint in perpetuity. All rights reserved. No reuse allowed without permission.

Supplementary material for: High-risk exposure without personal protective equipment and infection with SARS-CoV-2 in healthcare workers: results of the CoV-CONTACT prospective cohort, by Tubiana et al.

\section{Supplementary Table S1}

Immunological results obtained by the two serological methods (Lulisa $\mathrm{N}$ and EurolMMUN) in the 147 healthcare workers contact subjects with available data, following a high-risk exposure to SARSCoV-2 included in the CoV-CONTACT cohort.

\begin{tabular}{|l|l|c|c|c|}
\cline { 3 - 5 } \multicolumn{2}{c|}{} & \multicolumn{3}{c|}{ Euroimmun technique } \\
\cline { 3 - 5 } & No seroconversion & Seroconversion & Total \\
\hline \multirow{3}{*}{ Lulisa N technique } & No seroconversion & 116 & 2 & 118 \\
\cline { 2 - 5 } & Seroconversion & 3 & 26 & 147 \\
\cline { 2 - 5 } & Total & 119 & 28 & 29 \\
\hline
\end{tabular}


medRxiv preprint doi: https://doi.org/10.1101/2020.09.17.20194860; this version posted September 18, 2020. The copyright holder for this preprint (which was not certified by peer review) is the author/funder, who has granted medRxiv a license to display the preprint in perpetuity.

All rights reserved. No reuse allowed without permission.

Supplementary material for : High-risk exposure without personal protective equipment and infection with SARS-CoV-2 in healthcare workers: results of the CoV-CONTACT prospective cohort, by Tubiana et al.

Supplementary Table S2

Characteristics of the 123 healthcare workers contact subjects with confirmed SARS-CoV-2 infection and without infection following a high-risk exposure included in the COV-CONTACT cohort.

\begin{tabular}{|c|c|c|c|c|c|}
\hline & $\begin{array}{l}\text { All contacts } \\
\qquad(\mathrm{N}=123)\end{array}$ & $\begin{array}{c}\text { Contacts with } \\
\text { confirmed } \\
\text { SARS-CoV-2 } \\
\text { Infection* }(\mathrm{N}=37)\end{array}$ & $\begin{array}{l}\text { Contacts without } \\
\text { SARS-CoV-2 } \\
\text { infection } \\
(\mathrm{N}=83)\end{array}$ & OR $[95 \% \mathrm{Cl}]$ & P-value \\
\hline \multicolumn{6}{|l|}{ Contacts characteristics } \\
\hline Age (year) & $35[29 ; 47.5]$ & $35[29 ; 48]$ & $35[30 ; 47]$ & $1[0.97 ; 1.03]$ & 0.95 \\
\hline Male gender & $33 / 123(26.8 \%)$ & $9 / 37(24.3 \%)$ & $22 / 83(26.5 \%)$ & $0.89[0.35 ; 2.14]$ & 0.80 \\
\hline \multicolumn{6}{|l|}{ HCW functions } \\
\hline - Medical doctor / Resident / Midwife & $47 / 121(38.8 \%)$ & $11 / 36(30.6 \%)$ & $35 / 83(42.2 \%)$ & 1 (ref) & \\
\hline $\begin{array}{l}\text { - Registered Nurse / Certified nurse assistant / } \\
\text { Physiotherapists / Hospital students }\end{array}$ & $62 / 121(51.2 \%)$ & $23 / 36(63.9 \%)$ & $38 / 83(45.8 \%)$ & $1.93[0.83 ; 4.64]$ & 0.13 \\
\hline - Pharmacist / Admin istrative assistants & $12 / 121(9.9 \%)$ & $2 / 36(5.6 \%)$ & $10 / 83(12 \%)$ & $0.64[0.09 ; 2.91]$ & 0.59 \\
\hline \multicolumn{6}{|l|}{ Coexisting conditions } \\
\hline - Obesity (BMI>30Kg/m²) & $21 / 122(17.2 \%)$ & $7 / 37(18.9 \%)$ & $14 / 83(16.9 \%)$ & $1.15[0.4 ; 3.06]$ & 0.78 \\
\hline - Tobacco use & $27 / 123(22 \%)$ & $7 / 37(18.9 \%)$ & $19 / 83(22.9 \%)$ & $0.79[0.28 ; 2]$ & 0.63 \\
\hline - Cardiopathy & $6 / 122(4.9 \%)$ & $3 / 37(8.1 \%)$ & $3 / 83(3.6 \%)$ & $2.35[0.42 ; 13.28]$ & 0.31 \\
\hline - Chronic respiratory disease & $17 / 122(13.9 \%)$ & $3 / 37(8.1 \%)$ & $14 / 83(16.9 \%)$ & $0.43[0.1 ; 1.44]$ & 0.21 \\
\hline - Chronic kidney disease & $1 / 122(0.8 \%)$ & $1 / 37(2.7 \%)$ & $0 / 83(0 \%)$ & $\mathrm{NE}$ & 0.99 \\
\hline - Diabete & $1 / 122(0.8 \%)$ & $0 / 37(0 \%)$ & $1 / 83(1.2 \%)$ & $\mathrm{NE}$ & 0.99 \\
\hline - Immusuppressive therapy & $4 / 122(3.3 \%)$ & $1 / 37(2.7 \%)$ & $3 / 83(3.6 \%)$ & $0.74[0.04 ; 6.01]$ & 0.80 \\
\hline - Current pregnancy & $1 / 89(1.1 \%)$ & $0 / 28(0 \%)$ & $1 / 61(1.6 \%)$ & NE & 0.99 \\
\hline \multicolumn{6}{|l|}{ Type of exposition } \\
\hline Inclusion after the French lockdown & $55 / 123(44.7 \%)$ & $13 / 37(35.1 \%)$ & $40 / 83(48.2 \%)$ & $0.58[0.26 ; 1.28]$ & 0.19 \\
\hline Contact with more than one index & $22 / 123(17.9 \%)$ & $9 / 37(24.3 \%)$ & $13 / 83(15.7 \%)$ & $1.73[0.65 ; 4.48]$ & 0.26 \\
\hline \multicolumn{6}{|l|}{ Types of index subjects } \\
\hline - Contacts with SARS-CoV-2-infected HCW(s) only & $66(54.5 \%)$ & $12(33.3 \%)$ & $53(63.9 \%)$ & 1 (ref) & \\
\hline - Contacts with SARS-CoV-2-infected patient(s) only & $45(37.2 \%)$ & $19(52.8 \%)$ & $25(30.1 \%)$ & $3.36[1.43 ; 8.16]$ & 0.0061 \\
\hline $\begin{array}{l}\text { - Contacts with SARS-CoV-2-infected } \mathrm{HCW}(\mathrm{s}) \text { and } \\
\text { patient(s) }\end{array}$ & $10(8.3 \%)$ & $5(13.9 \%)$ & $5(6.0 \%)$ & $4.42[1.08 ; 18.39]$ & 0.036 \\
\hline Maximal SARS-CoV-2 viral load in the index subject & $9.3[7.5 ; 10.8]$ & $10.2[7.5 ; 10.8]$ & $8.7[7.5 ; 10.9]$ & $1.09[0.91 ; 1.3]$ & 0.36 \\
\hline Cumulated length of exposure $>30 \mathrm{~min}$ & $86 / 120(71.7 \%)$ & $25 / 35(71.4 \%)$ & $60 / 82(73.2 \%)$ & $0.92[0.39 ; 2.28]$ & 0.85 \\
\hline \multicolumn{6}{|l|}{ Exposure to a SARS-CoV-2-infected patient $(\mathrm{N}=70)$} \\
\hline - Care during an aerosol-generating procedure & $4 / 55(7.3 \%)$ & $0 / 24(0 \%)$ & $3 / 30(10 \%)$ & $\mathrm{NE}$ & 0.99 \\
\hline - Care without aerosol-generating procedure & $45 / 55(81.8 \%)$ & $20 / 24(83.3 \%)$ & $25 / 30(83.3 \%)$ & $1[0.23 ; 4.51]$ & $>0.99$ \\
\hline $\begin{array}{l}\text { - Presence in the patient's room during an } \\
\text { aerosol-generating procedure }\end{array}$ & $18 / 55(32.7 \%)$ & $9 / 24(37.5 \%)$ & $9 / 30(30.0 \%)$ & $1.4[0.45 ; 4.43]$ & 0.56 \\
\hline - Other type of contact & $9 / 55(16.4 \%)$ & $7 / 24(29.2 \%)$ & $2 / 30(6.7 \%)$ & $5.76[1.23 ; 41.82]$ & 0.041 \\
\hline \multicolumn{6}{|l|}{ Exposure to a SARS-CoV-2-infected HCW (N=95) } \\
\hline - Face-to-face discussion & $72 / 76(94.7 \%)$ & $16 / 17(94.1 \%)$ & $55 / 58(94.8 \%)$ & $0.87[0.1 ; 18.31]$ & 0.91 \\
\hline - Joint meeting & $22 / 76(28.9 \%)$ & $6 / 17(35.3 \%)$ & $16 / 58(27.6 \%)$ & $1.43[0.43 ; 4.45]$ & 0.54 \\
\hline - Lunch sharing & $17 / 76(22.4 \%)$ & $3 / 17(17.6 \%)$ & $14 / 58(24.1 \%)$ & $0.67[0.14 ; 2.45]$ & 0.58 \\
\hline - Other type of contact & $7 / 76(9.2 \%)$ & $1 / 17(5.9 \%)$ & $6 / 58(10.3 \%)$ & $0.54[0.03 ; 3.51]$ & 0.58 \\
\hline
\end{tabular}

* Contacts subjects with a possible SARS-CoV-2 infection (i.e., clinically-suspected without viro-immunological confirmation, $n=28$ ) were excluded.

SARS-CoV-2 infection could be determined for $120 / 123$ exposed contacts (missing data for immunological outcome $n=3$ ).

** Corticoids, chemotherapy, anti-rejection medication, etc.

Data are presented as $n(\%)$ or median [IQR]. NC, not estimable. 